\title{
ASSESSMENT OF C BUDGET FOR GRASSLANDS AND DRYLANDS OF THE WORLD
}

DENNIS S. OJIMA

BJØRN O.M. DIRKS

EDWARD P. GLENN

CLENTON E. OWENSBY

JONATHAN O. SCURLOCK.

\author{
Natural Resource Ecology Laboratory, Colorado \\ State University, Fort Collins, CO 80523 \\ Department of Theoretical Production Ecology, \\ Wageningen Agricultural University, P.O. Box \\ 430, 6700 AK Wageningen, The Netherlands \\ Environmental Research Laboratory, University \\ of Arizona, 2601 E. Airport Drive, Tucson, AZ \\ 85706-6985 \\ Department of Agronomy, Throckmorton Hall, \\ Kansas State University, Manhattan, KS 66506- \\ 5501 \\ Division of Life Sciences, King's College \\ London, Campden Hill Road, London W8 7AH, \\ United Kingdom
}

\begin{abstract}
Intergovernmental Panel on Climate Change (IPCC) estimates indicate that potential changes in seasonal rainfall and temperature patterns in central North America and the African Sahel will have a greater impact on biological response (such as plant production and biogeochemical cycling) and feedback to climate than changes in the overall amount of annual rainfall. Simulation of grassland and dryland ecosystem responses to climate and $\mathrm{CO}_{2}$ changes demonstrates the sensitivity of plant productivity and soil $\mathrm{C}$ storage to projected changes in precipitation, temperature and atmospheric $\mathrm{CO}_{2}$. Using three different land cover projections, changes in $\mathrm{C}$ levels in the grassland and dryland regions from 1800 to 1990 were estimated to be -13.2 , -25.5 and $-14.7 \mathrm{Pg}$, i.e., a net source of $\mathrm{C}$ due to land cover removal resulting from cropland conversion. Projections into the future based on a double- $\mathrm{CO}_{2}$ climate including climate-driven shifts in biome areas by the year 2040 resulted in a net sink of $+5.6,+27.4$ and $+26.8 \mathrm{Pg}$, respectively, based upon sustainable grassland management. The increase in $\mathrm{C}$ storage resulted mainly from an increase in area for the warm grassland sub-biome, together with increased soil organic matter. Preliminary modeling estimates of soil $\mathrm{C}$ losses due to $50 \mathrm{yr}$ of regressive land management in these grassland and dryland ecoregions result in a $11 \mathrm{Pg}$ loss relative to current conditions, and a potential loss of $37 \mathrm{Pg}$ during a $50 \mathrm{yr}$ period relative to sustainable land-use practices, an average source of $0.7 \mathrm{Pg} \mathrm{C} \mathrm{yr}^{-1}$. Estimates of the

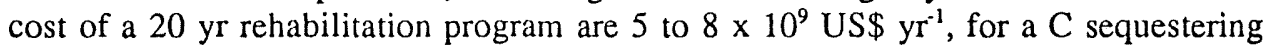
cost of approximately 10 US $\$$ per $\mathrm{tC}$.
\end{abstract}

Water, Air, and Soil Pollution 70: 95-109, 1993.

(c) 1993 Kluwer Academic Publishers. Printed in the Netherlands. 


\section{Introduction: Scope of the Problem}

Grasslands and associated savanna and shrublands are clearly vulnerable to climate change. The sensitivity of grasslands to climate change has been documented by observations of past droughts in the semiarid and arid regions (Weaver and Albertson, 1943; Hare, 1977; Schlesinger et al., 1990). Increased human activity has led to degradation of plant production and soil resources in many of these ecosystems leading to desertification in some regions (UNEP, 1991). The continuing pressure on these ecosystems and the projected modifications in regional climate indicate that further degradation of these lands will occur and that there is potential for still greater $\mathrm{C}$ losses.

Changes in seasonal rainfall and temperature patterns in central North America and the African Sahel will have a greater impact on biological response and feedback to climate than changes in the overall amount of annual rainfall (Houghton et al., 1990; Ojima et al., 1991). There are several ways in which changing climate and atmospheric $\mathrm{CO}_{2}$ concentrations may affect grassland and semi-arid ecosystems. Productivity of these ecosystems is directly linked to precipitation (Le Houerou, 1984; Sala et al., 1988; Parton et al., in press), so changes in precipitation amounts will affect plant production. These changes in production can modify soil $\mathrm{C}$ storage. The soil $\mathrm{C}$ store in these ecosystems is a very important pool, since it represents a significant proportion of the total system $\mathrm{C}$ and is stabilized for hundreds to thousands of years.

In the following analysis, several important features of the grassland and dryland region will not be covered in our assessment at this workshop. First, the soil C stored as inorganic constituents in these arid environments is substantial, but the flux rates from the carbonates are relatively small. Second, the paleosols, in certain regions, can also be an important $\mathrm{C}$ pool; however, there is no systematic way to deal with the exposure of these soils and subsequent oxidation of their stored $\mathrm{C}$. Third, invasion by or increase in woody species may be significant in grassland communities, and was not included in our climate change simulation. However, this is an indirect effect more closely linked to the frequency and intensity of burning and grazing (Archer, 1993, in press; Schlesinger et al., 1990).

Our considerations will deal with those changes in plant production and decomposition due to global change or to management practices which will impact the level of stored soil $\mathrm{C}$ on a time scale of decades to centuries. The following sections will discuss the grassland and dryland ecoregions being considered in this analysis, key ecological and biological issues related to the uptake and storage of $\mathrm{C}$ in these ecosystems, estimate the range of the $C$ source or sink of these ecoregions, and discuss the role of mitigation practices that would modify the magnitude of the source or the sink from the different grassland and dryland ecoregions. 


\section{Key Ecological Considerations for Assessment of Global Change in Grasslands and Drylands}

Grasslands by their very nature are resource-limited, particularly for $\mathrm{N}$ and water. In the natural grassland ecosystems considered here, essentially all nutrient resources are supplied by the system through nutrient cycling and water through precipitation. The seasonal distribution of rainfall is a major determinant of plant production in many semiarid and arid regions. Simulation of ecosystem responses to climate change in grassland regions of the world demonstrate the sensitivity of soil $\mathrm{C}$ storage and grassland biogeochemistry processes to seasonal distribution of precipitation changes and to overall increases in temperature (Ojima et al., 1991). Modifications of resource use efficiency among various grassland and aridland communities are important to projecting how these ecosystems will respond to increased atmospheric $\mathrm{CO}_{2}$, change in climate, or increases in atmospheric deposition of $\mathrm{N}$.

In addition, these semiarid and arid lands are vulnerable to human-induced land use changes, and these land uses affect soil $\mathrm{C}$ storage, soil fertility, soil erosion rates, dust loading into the atmosphere, trace gas exchange, and water and energy balances. The overall impact of these management practices on $\mathrm{C}$ storage in grassland and dryland soils are potentially greater than that of climate change or increased atmospheric $\mathrm{CO}_{2}$ concentrations.

In temperate grasslands, dominated by $\mathrm{C}_{3}$ species, they are also limited by $\mathrm{C}$ due to high photorespiration rates. These resource limitations result in relatively low net primary and secondary productivities, especially in the arid regions. Plants with the $\mathrm{C}_{3}$ photosynthetic pathway generally have increased $\mathrm{C}$ fixation rates when $\mathrm{CO}_{2}$ levels are increased, while $\mathrm{C}_{4}$ plants do not increase in $\mathrm{C}$ fixation to the degree that $\mathrm{C}_{3}$ plants do (Kimball, 1983). Photosynthetic capacity of plants with the $C_{3}$ pathway is limited by current atmospheric $\mathrm{CO}_{2}$ levels due to oxygenase activity of ribulose-1,5bisphosphate carboxylase (Rubisco). Innumerable studies have shown increased $\mathrm{C}_{3}$ photosynthesis with elevated $\mathrm{CO}_{2}$ (Newton, 1991). $\mathrm{C}_{4}$ photosynthesis is not considered $\mathrm{C}$-limited, because $\mathrm{C}$ is initially fixed in the mesophyll by phosphoenolpyruvate carboxylase (PEPc) which does not have oxygenase activity (Edwards and Walker, 1983). It appears that the grassland ecosystems dominated by $\mathrm{C}_{4}$ grasses will likely not experience increased $\mathrm{C}$ acquisition as a result of improved photosynthetic capacity (Knapp et al., 1993).

In ecosystems with frequent water stress, enhanced water-use efficiency due to partial stomatal closure in $\mathrm{CO}_{2}$-enriched environments is likely more important than photosynthetic pathway (Gifford et al., 1990). Morrison (1985) reviewed the literature concerning $\mathrm{CO}_{2}$ enrichment and water relations and reported a range of $60 \%$ to $160 \%$ increase in WUE for both $C_{3}$ and $C_{4}$ plants. For tallgrass prairie, increased above- and belowground biomass production under elevated $\mathrm{CO}_{2}$ without input of additional water has been reported (Owensby et al., 1993a; Knapp et al., 1993). Owensby et al. (1993a) reported increased root production with $\mathrm{CO}_{2}$ 
enrichment which would enhance water uptake. Changes in stomatal density may also impart water savings for plants under elevated $\mathrm{CO}_{2}$. Woodward (1987) indicated that $\mathrm{CO}_{2}$ enrichment over the past century has likely reduced stomatal density.

Any change in ecosystem function that improves productivity without additional $\mathrm{N}$ input will increase $\mathrm{N}$ use efficiency (NUE). NUE will almost certainly increase in most $\mathrm{N}$-poor ecosystems under elevated $\mathrm{CO}_{2}$. In natural grassland ecosystems, increased NUE was reported by Owensby et al. (1993b) in a $\mathrm{CO}_{2}$ enriched tallgrass prairie over a 3-yr period. Reduced $\mathrm{N}$ requirement in $\mathrm{N}$-limited systems may increase plant inputs into the soil system. The increased NUE will also result in a lower rate of decomposition due to changes in lower litter quality.

\section{Ecoregion Definition and Analytical Methods}

\subsection{GRASSLAND AND DRYLAND ECOREGION DEFINITION}

Grasslands and drylands in this assessment are defined as: Natural grasslands and drylands determined by climate (e.g., an aridity index [the ratio of annual precipitation to potential evaporation] between 0.05 and 0.8 ). Some savanna grasslands in the tropics are similarly determined by the presence of a short, but intense dry season. This definition, therefore, excludes hyper-arid regions but incorporates both the tropical and temperate grasslands of the world, including the humid savannas and grasslands which are maintained primarily by fire and grazing. However, we exclude two types of grassland areas from this analysis, namely:

* croplands previously converted from grasslands; and

* grass-dominated areas in eco-regions or life zones normally classified as forest. Pastures in both tropical and temperate regions which require large inputs of fertilizers or other intensive management are, therefore, not included in this analysis.

Given this definition of grasslands and drylands, we estimated the areal extent of these regions from the BIOME model developed by Prentice et al. (1992). Two other estimates of grasslands and dryland area were made using the UNEP (1991) land cover estimates of arid, semiarid, and subhumid regions of the world, and a separate estimate based on Bailey's (1989) Ecoregion approach used by Ojima et al. (1993, this volume). We assessed the given land areas for the various classes (Table 1) defined by UNEP (1991) and by Bailey (1989) and grouped them as best as possible according to the BIOME map (Prentice et al., 1992). Potential grassland and dryland regions were taken to be the pre-industrial areas of grassland and dryland and used to estimate "past land cover" (Table 2). Current grassland and dryland areas were obtained after accounting for conversion of a fraction of the cool 
Table 1. Grouping of grassland sub-regions as provided by Prentice et al. (1992), UNEP (1991) and Bailey (1989), according to the BIOME model of Prentice et al. (1992). Abbreviations: AA arid, SA semi-arid, SH sub-humid.

\begin{tabular}{||l|l|l||}
\hline Prentice et al. (1992) & \multicolumn{1}{|c|}{ UNEP (1991) } & \multicolumn{1}{|c|}{ Bailey (1989) } \\
\hline Semi-desert & AA Asia & dry continental \\
\hline Cool grass and shrub & SA Asia (x 0.577) & dry temperate \\
& SA South-America & \\
& (91 Mha) & \\
& SH Europe & \\
& SH Noth-America (x 0.5) & \\
\hline \multirow{5}{*}{ Warm grass and shrub } & AA Europe & humid temperate \\
& SA Africa & dry savanna \\
& Savanna \\
& SA Asia (x 0.423) & humid savanna \\
& SA Europe & mediterranean \\
& SA North-America & \\
& SA South-America & \\
& (174 Mha) & \\
& SH Africa & \\
& SH Asia & \\
& SH Australia & \\
& SH North-America (0.5) & \\
& SH South-America & \\
& AA Africa & \\
& AA Australia & \\
& AA North-America & AA South-America \\
\hline \multirow{5}{*}{ Hot desert } &
\end{tabular}

${ }^{1}$ Based on Bailey (1989)

${ }^{2}$ Based on Ojima et al. (1993, this volume)

and warm grasslands to arable land (Prentice et al., 1992). "Future" grassland and dryland extent was obtained from the $2 \mathrm{xCO}_{2}$ GFDL CGM climate change estimate of altered land cover area (Cramer and Solomon 1993; in review). In addition we subtracted the fraction of area under cropland estimated for the "current" land cover case (Table 2). 
Table 2. Changes in biome areas and carbon pools for grasslands and drylands for past, present and future.

\begin{tabular}{|c|c|c|c|c|c|c|c|}
\hline \multirow[b]{2}{*}{ BIO-REGION ${ }^{2}$} & \multicolumn{3}{|c|}{ BIOME AREAS } & \multicolumn{4}{|c|}{ CARBON POOLS ${ }^{1}$} \\
\hline & POTENTIAL & CURRENT & FUTURE & PAST & CURRENT & $\begin{array}{c}\text { FUTURE } \\
\text { "REGRESSIVE" }\end{array}$ & $\begin{array}{l}\text { FUTURE } \\
\text { "SUSTAINABLE" }\end{array}$ \\
\hline & 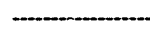 & ..... M ha $\ldots$ & $\ldots$ & $\ldots$ & $\ldots$ & $-\mathrm{Pg}$ & - \\
\hline SEMI-DESERT & $\begin{array}{l}\text { 3a) } 499.5 \\
\text { b) } 626.0 \\
\text { c) } 137.1\end{array}$ & $\begin{array}{l}499.5 \\
626.0 \\
137.1\end{array}$ & $\begin{array}{c}298.9 \\
374.6 \\
82.0\end{array}$ & $\begin{array}{r}27.620 \\
34.615 \\
7.581\end{array}$ & $\begin{array}{r}27.620 \\
34.615 \\
7.581\end{array}$ & $5.2(-2.38)$ & $\begin{array}{c}15.740(-11.9) \\
19.726(-14.9) \\
4.318(-3.3)\end{array}$ \\
\hline COOL GRASS/SHRUB & $\begin{array}{l}\text { a) } 571.3 \\
\text { b) } 791.0 \\
\text { c) } 304.0\end{array}$ & $\begin{array}{l}272.5 \\
377.3 \\
145.0\end{array}$ & $\begin{array}{l}121.3 \\
167.9 \\
86.8\end{array}$ & $\begin{array}{l}11.642 \\
16.120 \\
6.195\end{array}$ & $\begin{array}{l}5.553(-6.1)^{4} \\
7.689(-7.6) \\
2.955(-3.2)\end{array}$ & $2.26(-6.95)$ & $\begin{array}{l}1.789(-3.7) \\
2.477(-5.2) \\
1.280(-1.7)\end{array}$ \\
\hline WARM GRASS/SHRUB & $\begin{array}{l}\text { a) } 1180.5 \\
\text { b) } 2821.0 \\
\text { c) } 1892.6\end{array}$ & $\begin{array}{l}1016.4 \\
2428.9 \\
1629.5\end{array}$ & $\begin{array}{l}1460.3 \\
3489.5 \\
2341.1\end{array}$ & $\begin{array}{c}51.258 \\
122.493 \\
82.178\end{array}$ & $\begin{array}{c}44.133(-7.1) \\
105.466(-17.0) \\
70.755(-11.4)\end{array}$ & $63.00(-7.75)$ & $\begin{array}{c}63.725(+19.6) \\
152.282(+46.8) \\
102.166(+31.4)\end{array}$ \\
\hline HOT DESERT & $\begin{array}{l}\text { a) } 1945.5 \\
\text { b) } 934.0 \\
\text { c) }-\end{array}$ & $\begin{array}{c}1945.5 \\
934.0 \\
-\end{array}$ & $\begin{array}{c}2004.1 \\
962.1 \\
-\end{array}$ & $\begin{array}{c}34.336 \\
16.484 \\
-\end{array}$ & $\begin{array}{c}34.336 \\
16.484 \\
-\end{array}$ & & $\begin{array}{l}35.651(+1.3) \\
17.115(+0.6)\end{array}$ \\
\hline TOTAL & $\begin{array}{l}\text { a) } 4196.8 \\
\text { b) } 5172.0 \\
\text { c) } 2333.7\end{array}$ & $\begin{array}{l}3733.9 \\
4366.2 \\
1911.6\end{array}$ & $\begin{array}{l}3844.6 \\
4994.1 \\
1509.9\end{array}$ & $\begin{array}{l}124.856 \\
189.712 \\
95.954\end{array}$ & $\begin{array}{l}111.642(-13.2) \\
164.254(-25.5) \\
81.291(-14.7)\end{array}$ & $70.46(-10.82)$ & $\begin{array}{l}116.905(+5.6) \\
191.600(+27.0) \\
107.764(+26.8)\end{array}$ \\
\hline
\end{tabular}

'Carbon pools are total soil $\mathrm{C}$ t $20 \mathrm{~cm}$ deph as modeled using CENTURY (Ojima et al., 1993, this volume). An approximate value for soil $\mathrm{C}$ to $1.0 \mathrm{~m}$ depth may be obtained by multiplying these values by 3-4. Thus, current grassland and dryland soil carbon (range 96 to $190 \mathrm{Pg}$ average $119 \mathrm{Pg}$ to a depth of $20 \mathrm{~cm}$ ) is approximately $417 \mathrm{Pg}$ to a depth of $1.0 \mathrm{~m}$.

${ }^{2}$ Biomes as defined by Prentice et al. (1992).

a) Areas for biomes defined by Prentice et al. 1992.

b) Areas derived from UNEP-based aridity index (UNEP, 1991).

c) Areas derived from Bailey Ecoregions (Bailey 1988).

-Values in parentheses indicate net flux in $\mathrm{C}$ pools from one period to the nex 


\subsection{ESTIMATING C STORAGE AND FLUXES RELATIVE TO GLOBAL CHANGE}

Carbon storage and flux estimates from grassland and dryland regions were estimated under a prescribed climate change scenario (GFHI, IPCC Report, Houghton et al., 1990) and land cover estimates described previously and given in Table 2. The grassland model of CENTURY (Parton et al., 1987, 1992; Parton et al., in press b), was used for the simulations of aboveground net primary productivity (NPP) and soil organic C (SOC) to a depth of $20 \mathrm{~cm}$ for 31 sites across the globe (Ojima et al., $1993 \mathrm{~b}$, in press). Results from three sets of simulations were used.

* Current climate scenarios using acceptable land management practices;

* Combined effect of climate change and doubling of atmospheric $\mathrm{CO}_{2}$ $\left(+\mathrm{CC}+\mathrm{CO}_{2}+\mathrm{M}\right)$ using acceptable or sustainable land management practices; and

* Combined effect of clin.ate change and doubling of atmospheric $\mathrm{CO}_{2}$ $\left(+\mathrm{CC}+\mathrm{CO}_{2}-\mathrm{M}\right)$ using unacceptable or regressive land management.

We modified the plant production parameters under a $2 \times \mathrm{CO}_{2}$ climate by changing production relative to potential evapotranspiration (PET) and to $\mathrm{N}$ use efficiency (NUE). The magnitude of the effect is to cause a $20 \%$ increase in plant production with a change in atmospheric $\mathrm{CO}_{2}$ concentration from 350 to 700 ppm (Ojima et al., 1993, this volume).

In order to generate the double $\mathrm{CO}_{2}$ climate, we spatially interpolated $\mathrm{GCM}$ grid values of projected $2 \times \mathrm{CO}_{2}$ climate changes of monthly temperature $(\mathrm{T})$ and precipitation (PPT) for each site based on the GCM output made for the 1990 IPCC report (Kittel, pers. comm., NCAR data retrieval system). We applied these projected monthly values in a linear fashion in a $50 \mathrm{yr}$ ramp (see Ojima et al., 1993, this volume).

\section{Regional Ecosystem Modeling}

For regional simulations, we selected a representative climate for each site within a region and simulated equilibrium ecosystem levels of soil $\mathrm{C}$ and plant production. Climate change simulations for a particular region was based on these representative sites and estimates of climate and $\mathrm{CO}_{2}$ induced modifications to ecosystem dynamics were applied evenly across the region.

Past soil $\mathrm{C}$ pools under grassland were calculated using current soil organic matter content projected over a pre-industrial land use scenario (Table 2). Future soil C pools were calculated using both soil organic matter content occurring for a so-called 'regressive management' future scenario, accounting for removal of $50 \%$ of the aboveground biomass during grazed months, and an 'sustainable' scenario using the 
same moderate grazing and burning regimes specified by Ojima et al. (1993; this volume).

\subsection{CARBON CHANGES IN THE GRASSLAND AND ARID REGIONS IN THE PAST, PRESENT, AND FUTURE}

The results from the "climate change scenario only" (i.e., using only projected changes in monthly rainfall and temperature levels and not $\mathrm{CO}_{2}$ enhancement effects) indicate that soil $\mathrm{C}$ losses occur in all grassland regions (losses range from near 0 to $14 \%$ of current soil C levels for the surface $20 \mathrm{~cm}$ ). Plant production varies according to modifications in rainfall amounts under the altered climate and to altered $\mathrm{N}$ mineralization rates. Soil decomposition rates responded most predictably to changes in temperature. $\mathrm{CO}_{2}$ enhancement effects on plant production and the indirect effects on soil $\mathrm{C}$ loss tended to reduce the net impact of climate alterations in most of the regions, and actually resulted in net $\mathrm{C}$ sinks in the warm grasslands regions.

Using the sustainable land-management regime, results indicate that changes in soil C levels in the grassland and dryland regions from 1800 to 1990 are losses of -13.2, -25.5 and $-14.7 \mathrm{Pg}$ (based on land area estimates of Prentice, UNEP and Bailey, respectively, Table 2). The net loss of soil $\mathrm{C}$ is due primarily to land use conversion to cropland. Projections into the future based on a double- $\mathrm{CO}_{2}$ climate including climate-driven shifts in biome areas by the year 2040 resulted in a net sink of +5.6 , +27.4 and $+26.8 \mathrm{Pg}$, respectively, based upon sustainable grassland management. The increase in $\mathrm{C}$ storage in this future projection resulted mainly from an increase in area for the warm grassland sub-biome (net increase of $280 \mathrm{M}$ ha due to climatechange induced biome shifts) together with a net increase in soil organic $\mathrm{C}$ densities for the sites simulated in this sub-biome (Table 2).

We simulated "regressive" land management by increasing grazing levels from $30 \%$ to $50 \%$ removal for all of the sites analyzed. The impact of "regressive" land management resulted in a loss of soil $\mathrm{C}$ in all regions after 50 yrs (Table 2 "Future regressive" column). Largest losses were evident in the warm grasslands. The total net loss relative to current condition is $10.8 \mathrm{Pg}$. When this regressive management is compared to a sustainable management system (i.e., light grazing) the net difference is $37.6 \mathrm{Pg}$ gain of soil C. Modification of land use practices can greatly influence the net flux of soil $\mathrm{C}$, changing grasslands from a source of $\mathrm{C}$ to a sink for atmospheric $\mathrm{C}$.

\subsection{AN ALTERNATIVE SOURCE/SINK ESTIMATE}

Using the logic described by Gifford et al. (1990), estimates of annual C sequestration in grassland sinks can be alternatively derived. They hypothesized that given the continuous $\mathrm{C}$ exchange between live hiomass, soil organic matter pools, and the atmosphere with turnover times in grassland ecosystems from 7 to $10 \mathrm{yr}$, 
changes in one pool would eventually be distributed to the other linked pools. Accordingly, they surmised that an increase in atmospheric $\mathrm{CO}_{2}$ would be accompanied by an increase in $\mathrm{C}$ stored in live vegetation, the dead litter, and the soil C. The mechanisms involved are likely increased $\mathrm{C}$ fixation due to increased photosynthetic capacity and resource use efficiencies, and decreased decomposition rates. Basic assumptions relevant to $\mathrm{C}$ storage in grassland ecosystems include (i) turnover times for plant $\mathrm{C}$ are a decade or less; and (ii) changes in $\mathrm{C}: \mathrm{N}$ ratios of plant biomass may reduce decomposition rates (Gifford et al., 1990).

Calculations based on those of Gifford et al. (1990) suggest that the present $\mathrm{C}$ flux in grassland soils (estimated at $417 \mathrm{Pg}$; Table 2), may be a net sink of $0.6 \mathrm{Pg} \mathrm{yr}^{-1}$ an upper limit. Owensby (1993; this volume) suggested that additional $\mathrm{C}$ storage in grassland soils could be as high as 25 to $30 \%$ with $\mathrm{CO}_{2}$ doubling over the next 50 to $70 \mathrm{yrs}$, i.e., an annual increase of 0.4 to $0.5 \%$. The grassland sink would be in the range of 1.7 to $1.8 \mathrm{Pg} \mathrm{yr}^{-1}$, a number which we regard as an extreme upper limit. The of $0.6 \mathrm{Pg} \mathrm{yr}^{-1}$ sink should be regarded only as an alternative estimate of the upper limit for a possible grassland soil sink. The CENTURY model analysis of global grassland ecosystem sensitivity to climate change and $\mathrm{CO}_{2}$ enhancement shows that changes in temperature and precipitation may more than offset the additional $\mathrm{C}$ storage produced by $\mathrm{CO}_{2}$ enhancement (see Table 2).

\section{Policy Issues}

Semiarid and arid regions may be among the more sensitive terrestrial ecosystems with respect to global change effects, resulting in severe degradation of their potential to store C (OIES, 1991). Changes which decrease soil moisture and nutrient availability may result in large declines in both soil $\mathrm{C}$ and plant productivity. Under these conditions, human activities leading to desertification of certain ecosystems will be greatly accelerated. In the following section we outline an estimation of the level of $\mathrm{C}$ lost and the potential for conserving soil $\mathrm{C}$.

\subsection{COST OF SEQUESTERING C THROUGH ANTI-DESERTIFICATION PROGRAMS IN THE GRASJLANDS AND RANGELANDS}

The CENTURY model estimates a potential soil $C$ flux to the atmosphere from most grassland regions under scenarios of $\mathrm{CO}_{2}$ enrichment and climate change. The scenarios assume a sustainable land management strategy with respect to fire and grazing pressure and preservation of native plant types. In contrast to this sustainable land management scenario, UNEP (Dregne et al., 1991) has estimated the extent of current land degradation and the projected rate given minimal antidesertification measures. It has itemized the costs of a $20 \mathrm{yr}$ program to arrest land degradation and restore already degraded lands (Kassas et al., 1991). 
Soil $\mathrm{C}$ fluxes are driven in part by net primary productivity on the land surface. Desertification results in reductions in net primary productivity. Hence, it is theoretically possible to calculate the differences in soil $\mathrm{C}$ storage between scenarios of sustainable management versus current levels of regressive management projected into the future using the CENTURY model and UNEP data. The cost of antidesertification measures, divided by the difference in annual $\mathrm{C}$ flux rates between the two scenarios yields a theoretical price per tonne of mitigating $\mathrm{C}$ losses into the atmosphere by restoring degraded drylands. Before performing the calculations it is necessary to examine some of the underlying assumptions and uncertainties.

\subsection{STATUS OF THE GRASSLANDS AND DRYLANDS UNDER PRESENT AND FUTURE MANAGEMENT SCENARIOS}

The extent of present land degradation is documented in UNEP (1991). Their data were derived from two global data bases: GLASOD (International Soil Reference and Information Center, Wageningen, an index of soil degradation) and an ICASALS data base (Texas Tech University) on land degradation. The combined data were used to estimate the extent of land degradation in the rangelands of the world (Table 3). UNEP does not quantify percentage reduction in net primary productivity in each degradation class, but from the verbal descriptions we infer that moderate degradation is approximately 25 to $50 \%$, severe 50 to $75 \%$ and very severe $>75 \%$ loss of net primary productivity due to land use practices. At present, $70 \%$ of rangelands $(3.32 \mathrm{Bha})$ are at least moderately degraded and UNEP estimates that desertification is increasing at an annual rate of $3.5 \%$, defined by the percentage of the land base passing into a higher-degradation category from case-study data for eight well-studied countries. For the purpose of the calculations, we have assumed that the grazing removal rate is $50 \%$ using the site specific grazing management practices projected over $50 \mathrm{yr}$, compared to $30 \%$ removal rate for the sustainable management scenario. Again, we believe this to be a conservative projection from the UNEP data.

Differences in $\mathrm{C}$ flux between the two management scenarios were derived from the CENTURY model and are justified separately. They predict that over $50 \mathrm{yr}$ the difference in $\mathrm{C}$ emissions between the regressive land use scenario and the progressive or optimal management scenario will be $37 \mathrm{Pg}$ (annual difference $=0.7$ $\mathrm{Pg}$ ) over the whole land base under consideration (4.5 Bha of grasslands and rangelands). This is a significant rate of sequestration (ca. 12\% of fossil fuel $\mathrm{C}$ emissions). It is important to note that the half-life of the $37 \mathrm{Pg}$ (net) stored soil C is measured in hundreds of years. This is a much longer storage interval than can be achieved with tree plantations, forest preservation, or other sequestration scenarios that depend upon storing $\mathrm{C}$ in aboveground standing crop. 
Table 3. Extent of desertification in rangelands within the drylands of the world (Dregne et al., 1991).

\begin{tabular}{||l|l|l|l|l|l||}
\hline Mha & Slight-none & Moderate & $\begin{array}{l}\text { Severe- } \\
\text { moderate }\end{array}$ & Very Severe & Total \\
\hline Africa & 347 & 274 & 716 & 5.3 & 995 \\
\hline Asia & 384 & 485 & 692 & 10.8 & 1188 \\
\hline Australia & 296 & 277 & 55 & 29.0 & 361 \\
\hline Europe & 31 & 27 & 52 & 1.2 & 81 \\
\hline N. America & 72 & 116 & 285 & 10.2 & 411 \\
\hline S. America & 93 & 88 & 184 & 15.3 & 288 \\
\hline Total & 1223 & 1267 & 1984 & 71.8 & 3323 \\
\hline
\end{tabular}

\subsection{COSTS OF ACHIEVING AN OPTIMUM MANAGEMENT SCENARIO}

UNEP has developed a detailed series of regional plans for anti-desertification (Kassas et al., 1991). The programs include afforestation, reforestation, planting of shrubs and grasses, control of grazing lands, planting halophytes on salinized land for animal feed and to sequester C (Glenn et al., 1992), and numerous other remediation methods. Costs depend upon the severity of degradation and the intensity of land use (Table 4).

The urgency of initiating anti-desertification actions can be seen from Table 5 - as desertification proceeds, costs rise dramatically as land passes into higher degradation categories which require greater expense per unit of land. Our present concern is only with the rangelands (non-croplands) in Table 4. Annual costs to restore this land base are in the range 5.0 to $8.8 \times 10^{9}$ US $\$$. Divided by the mean annual sequestration rate (i.e., $0.7 \mathrm{Pg}$ per $\mathrm{yr}^{-1}$ ), the cost per $\mathrm{t} \mathrm{C}$ is about 10 US $\$$. This estimate is within the range of estimates that have been calculated for forest sequestration schemes. However, as noted below, there are other policy considerations in regard to rehabilitating the drylands.

\subsection{COSTS OF NOT CONDUCTING ANTI-DESERTIFICATION IN THE DRYLANDS}

UNEP (1991) estimates the average annual income foregone due to degraded rangelands to be $23 \times 10^{9}$ US $\$ \mathrm{yr}^{-1}$. They calculate the cost:benefit ratio of restoring the rangelands as $1: 3.5$ on a global basis. However, the large sums of money required for investment in restoration have not been generally made available 
Table 4. Global costs in $10^{9}$ US $\$$ for a 20 yr program of direct anti-desertification measures (UNEP, 1991).

\begin{tabular}{||l|l|l|l|l||}
\hline & \multicolumn{2}{|c|}{ Cropland } & & \\
\hline & Irrigated & Rain-fed & Rangelands & Cost $\mathrm{yr}^{-1}$ \\
\hline Preventive measures & $10-31$ & $12-36$ & $6-18$ & $0.3-.9$ \\
\hline Corrective measures & $17-50$ & $18-55$ & $13-38$ & $0.7-1.9$ \\
\hline Rehabilitation measures & $21-41$ & $22-59$ & $80-120$ & $4-6$ \\
\hline Total & & & $99-176$ & $5-8.8$ \\
\hline
\end{tabular}

Table 5. Global average indicative costs for direct antidesertification measures in different land use systems (US\$) (UNEP, 1991).

\begin{tabular}{||l|l|c|c||}
\hline \hline $\begin{array}{l}\text { Extent of } \\
\text { Degradation }\end{array}$ & Cost of Restoration & \multicolumn{2}{|c|}{ US\$ ha ${ }^{-1}$} \\
\hline Slight/None & $100-300$ & $50-150$ & $5-15$ \\
\hline Moderate & $500-1500$ & $100-300$ & $10-30$ \\
\hline Severe & $2000-4000$ & $500-1500$ & $40-60$ \\
\hline Very Severe & $3000-5000$ & $2000-4000$ & $30-70$ \\
\hline
\end{tabular}

(Kassas et al., 1991). The funds required for restoration are available internally for the industrialized regions (N. America and Australia) and the oil-producing regions (the Middle East), but the developing countries in arid zones of Africa and Asia will require external support to conduct anti-desertification on a meaningful scale. The failure of past anti-desertification programs in these regions has been attributed directly to lack of funding (UNEP, 1991).

\subsection{OTHER POLICY CONSIDERATIONS}

The question of social equity needs to be considered. Should development and environmental projects be judged primarily on their net ability to sequester $\mathrm{C}$ in the future? If a massive transfer of payments from industrialized to developing countries for the purpose of $\mathrm{C}$ offsets occurs, will the decisions be based solely on storing the most $\mathrm{C}$ at the lowest price, even if there are no social benefits, or will priority be given to schemes which are necessary even in the absence of global warming? 
A major concern is whether anti-desertification measures, even if fully funded, can be effective. Technical solutions to rehabilitating rangelands are available but if population increases put additional pressure on the landscape, desertification may continue despite external funding for anti-desertification programs.

\section{Research Perspective}

A number of research needs were identified at the workshop that would alleviate gaps in our current knowledge of grasslands and dryland ecosystems responses to changing atmospheric $\mathrm{CO}_{2}$ and climate conditions. These research needs include:

Ecophysiology and Ecosystem Science - Response of natural ecosystems, above and below ground, across broad climate gradients to elevated $\mathrm{CO}_{2}$ with particular emphasis on changes in relationships among environmental variables such as temperature, moisture, and nutrients. In mixed $\mathrm{C}_{3}-\mathrm{C}_{4}$ ecosystems, determination of differential responses among species that affect productivity and interspecific competition leading to composition shifts. Particular emphasis should be placed on carbon pool quantification over time and space for selected ecosystems.

Land Use Management - Response of natural ecosystems to elevated $\mathrm{CO}_{2}$ under traditional and anticipated management, including sustainable, rehabilitative, and regressive strategies utilizing, for example, grazing, fire, and conversion strategies.

Modeling of Ecosystem and Ecophysiological Responses - Using data obtained from the ecophysiology and management research, models should simulate responses across all scales. Modeling efforts are currently constrained by inadequate databases of ecosystem responses to elevated $\mathrm{CO}_{2}$ for essentially all ecosystems. In addition, collaboration with development and application of data bases that include land cover, land use, and soils. This would facilitate projections of future scenarios for assessment purposes.

Monitoring and Coordination of Research Efforts - Long-term assessments of grassland and dryland ecosystem productivity, above and below ground, in response to year-on-year variation in climate (temperature, precipitation, etc.), concentrated at a series of study sites covering the whole range of these ecosystems. These measurements should be combined with more extensive monitoring over large areas using techniques such as satellite and aircraft remote sensing. Research efforts at all sites should be coordinated to provide relatively uniform data collection and synthesis methodologies required to produce databases for efficient distribution to varied uses. 


\section{Summary}

The potential effects of management on carbon storage in grassland and dryland soils are substantially greater than that of climate change or $\mathrm{CO}_{2}$ enhancement. Projections into the future based on a double- $\mathrm{CO}_{2}$ climate including climate-driven shifts in biome and accounting for cropland areas by the year 2040 resulted in a net $\mathrm{C}$ sink ranging from $+5.6 \mathrm{Gt}$ to $+27.4 \mathrm{Gt}$, for three different land cover projections respectively, based upon optimal grassland management. The increase in $\mathrm{C}$ storage in this future projection resulted mainly from an increase in area for the warm grassland sub-biome (net increase of $280 \mathrm{M}$ ha due to climate-change induced biome shifts) together with a net increase soil organic $\mathrm{C}$ density resulting from net ecosystem response to climate changes and enhanced $\mathrm{CO} 2$ concentrations.

Differences in $\mathrm{C}$ flux between sustainable and regressive management scenarios were derived from the CENTURY model and are justified separately. They predict that over $50 \mathrm{yr}$ the difference in carbon emissions between the regressive scenario and the sustainable management scenario will be $37 \mathrm{Gt}$ (annual difference $=0.7 \mathrm{Gt}$ ) over the whole land base under consideration (4.5 $\mathrm{B}$ ha of grasslands and rangelands). The cost per $\mathrm{t} C$ is around US $\$ 10$. This estimate is within the range of estimates that have been calculated for forest sequestration schemes.

The soil store of $\mathrm{C}$ in these ecosystems is a very important pool, since it is stabilized for hundreds to thousands of years, and forms the bulk of the grassland $\mathrm{C}$ pool. Calculations based on those of Gifford et al. (1990) suggest that the present $\mathrm{C}$ pool in grassland soils (estimated at $417 \mathrm{Gt}$; Table 2), may be a net sink of $0.6 \mathrm{Gt}$ per annum.

\section{References}

Archer S.: 1993, in: Varra M., W. Laycock and R. Pieper (eds), Ecological implications of livestock herbivory in the West, Society for Range Management (in press).

Bailey, R.G.: 1989, Environmental Conservation 16, 307-309.

Cramer, W.P. and Solomon, A.M.: 1993, Climatic Research (in review).

Dregne, H., Kassas, M. and Rosanov, B.: 1991, Desertification Control Bulletin 20, 6-18. United Nations Environment Programme, P.O. Box 30552, Nairobi, Kenya.

Edwards, G., and Walker, G.: 1983, $C_{3}, C_{4}$ : Mechanisms, and Cellular and Environmental Regulation, of Photosynthesis. 542 p. Blackwell, Oxford.

Gifford, R.M., Cheney, N.P., Noble, J.C., Russell, J.S., Wellington, A.B. and Zammit,C.: 1990, in: Australia's Renewable Resources: Sustainability and Global Change, Gifford, R.M. and M.M. Barson (eds) Bureau of Rural Resources Proceedings No. 14. Resource Assessment Commission, Queen Victoria Terrace, Parkes ACT 2600. pp. 151-187. 
Glenn, E.P., Hodges, C., Leith, H., Pielke, R. and Pitelka, L.: 1992, Environment 34, 40-43.

Hare F.K.: 1977, in: Desertification: its causes and consequences, United Nations Conference on Desertification, Nairobi, Kenya, Pergamon Press, Oxford UK.

Houghton, J.T., Jenkins, G.J. and Ephraums, J.J. (eds): 1990, Climate Change. The IPCC Scientific Assessment, World Meteorological Organization (WMO), Cambridge University Press, Cambridge.

Kassas, M., Ahmad, Y. and Rosanov, B.: 1991, Desertification Control Bulletin 20, 19-29.

Kimball, B.A.: 1983, Agron. J. 75, 779-788.

Knapp, A.K., Hamerlynck, E.P. and Owensby, C.E.: 1993, Environmental and Experimental Botany (in press)

Le Houerou, H.N.: 1984, J. Arid Environments 7, 1-35.

Morrison, J.I.L.: 1985, Plant, Cell and Environment 8, 467-474.

Newton, P.C.D.: 1991, New Zealand J. Agr. Res. 34, 1-24.

OIES: 1991, Arid and semi-arid regions: response to climate change, Office of Interdisciplinary Earth Science, Boulder, Colorado, USA.

Ojima, D.S., Kittel, T.G.F., Rosswall, T. and Walker, B.H.: 1991, Ecol. Appl. 1, 316325.

Ojima, D.S., Parton, W.J., Schimel, D.S., Scurlock, J.M.O. and Kittel, T.G.F.: 1993, Water, Air, and Soil Pollution (this volume).

Owensby, C.E., Coyne, P.I., Ham, J.M., Auen, L.M. and Knapp, A.K.: 1993a, Ecological Applications (in press)

Owensby, C.E., Coyne, P.I. and Auen, L.M.: 1993b, Plant, Cell and Environment.

Owensby, C.E., 1993, Water, Air, and Soil Pollution (this volume).

Parton, W.J., Schimel, D.S., Cole, C.V. and Ojima, D.S.: 1987, Soil Science Society of America Journal 51, 1173-1179.

Parton, W.J., McKeown, B., Kirchner, V. and Ojima, D.: 1992, CENTURY Users' Manual, Natural Resource Ecology Laboratory, Colorado State University, Fort Collins CO 80523, USA.

Parton, W.J., Coughenour, M.B., Scurlock, J.M.O., Ojima, D.S., Gilmanov, T.G., Scholes, R.J., Schimel, D.S., Kirchner, T., Menaut, J-C., Seastedt, T., Garcia, E. Moya, Kamnalrut, A., Kinyamario, J.L. and Hall, D.O.: 1993a, Global Biogeochemical Cycles.

Parton, W.J., Schimel, D.S., Ojima, D.S. and Cole, C.V.: 1993b, submitted, Soil Science Society of America Journal (in press b).

Prentice, I.C., Cramer, W., Harrison, S.P., Leemans, R., Monserud, R.A. and Solomon, A.M.: 1992, Journal of Biogeography 19, 117-134.

Sala, O.E., Parton, W.J., Joyce, L.A. and Lauenroth, W.K.: 1988, Ecology 69, 40-45.

Schlesinger, W.H., Reynolds, J.F., Cunningham, G.L., Huenneke, L.F., Jarrell, W. M., Virginia, R.A. and Whitford, W.G.: 1990, Science 247, 1043-1048.

UNEP: 1991, UNEP Governing Council decision - desertification, Desertification Control Bulletin 20, 3-5.

Weaver, J.E. and Albertson, F.W.: 1943, Ecological Monographs 13, 63-118.

Woodward, F.I.: 1987, Nature 327, 617-618. 